\title{
Survey of Physician Perspective towards Management of Pain for Chronic Conditions in the Emergency Department
}

\author{
Daniel Sop ${ }^{1,2 *}$, Wally Smith ${ }^{1}$, Abdulkhaliq Alsalman ${ }^{1}$, Jennifer Li Wong ${ }^{1}$, Ding-Yu Fei², Donna \\ McClish $^{4}$, Azhar Rafiq ${ }^{3}$, Patrick Coyne ${ }^{5}$, Shirley Johnson ${ }^{1}$, Thokozeni Lipato ${ }^{1}$ \\ ${ }^{1}$ Deptment of General Internal Medicine \\ ${ }^{2}$ Deptment of Biomedical Engineering \\ ${ }^{3}$ Deptment of Surgery \\ ${ }^{4}$ Deptment of Biostatistics, Virginia Commonwealth University, Richmond, VA 23298, USA \\ ${ }^{5}$ Department of Palliative care, Medical University of South Carolina, Charleston, SC 29425, USA \\ Email: sopdm@vcu.edu
}

\begin{abstract}
Sickle cell disease (SCD) pain is often acute-on-chronic, likening it to other chronic acuteon-chronic pain conditions. Pain treatment of SCD was already reported as inadequate prior to the current opioid epidemic, but attitudes underlying treatment were understudied. Understanding these attitudes prior to the current epidemic would be revealing. Therefore in 1997, before the current opioid epidemic, we surveyed physicians' attitudes toward pain management and treatment preferences for acute pain exacerbations in the Emergency Department in SCD versus those of chronic pancreatitis and chronic low back pain, two other acute-on-chronic pain diseases. Thirty-nine residency trainees were surveyed in a level one triage hospital. Resident estimates of the rate of opioid addiction in SCD were higher than estimates in both chronic pancreatitis and chronic low back pain. Most residents relied on their personal clinical experience rather than external sources of data or knowledge as the most important driver when they managed chronic pain. This survey research shows that, predating the current opioid epidemic, there was both a backdrop of opioidphobia and a bias against treating SCD pain compared to other chronic pain conditions among our sample. Repeating this survey research among current training physicians, along with surveys of other attitudes, would provide useful comparisons.
\end{abstract}

Keywords: Pain management, sickle cell disease, opioids, chronic pain, internal medicine physicians

\section{Introduction}

The epidemic of opioid overdose and accidental death in the US is evidenced by the Centers for Disease Control finding that prescribing higher doses of opioids, measured as $>50$ morphine milligram equivalents per day (MME/day), is related to higher risk of accidental death from opioids.[1] In 2012, more than a bottle's worth of opioids were prescribed per American adult.[2] In 2013, the mean total $\mathrm{MME} /$ day in 8 states was 57.8 to $82.1 \mathrm{MME} /$ day; $8.1 \%$ to $16.0 \%$ got $>100 \mathrm{MME} /$ day.[3]

However, prior to the opioid epidemic, some physicians definitely tended toward opioid-phobia and inadequate treatment of pain, especially chronic pain. Under-medicating of expressed pain with opioid analgesics was deemed a pervasive problem, even after decades of attention to the problem. [4]Caregivers might know when patients were in pain, but might discount patients' ratings of pain severity.[5] Caregivers might attribute less intense pain or lower priority to administering analgesia when patients had no signs of pathology, when duration was long-term and chronic, or when pain was not accompanied by negative affective expressions. $[6,7,8]$

Several factors were found to empirically predict how caregivers rated patients' pain or how intensely they treated their pain. For cancer pain, predictors of (barriers to) prescribing opiates were classified as societal barriers, knowledge deficits, and influence of governmental regulations.[9] For example, fear of addiction, of respiratory depression and of other side-effects could relate to a knowledge deficit. [10] This classification scheme for cancer pain was thought to extend to non-cancer conditions. For example, failure of pharmacies in urban, nonwhite neighborhoods to stock opiates [11] may have related to concerns about robbery and federal or state investigation. [12] 
One of the most important predictors of management was health care providers' attitudes about addiction in chronic pain populations. Providers with these attitudes likely withheld opioids for fear of causing addiction[13], fear of losing their license, or fear of killing or crippling patients due to respiratory suppression, cardiac arrhythmias[14], pulmonary edema, nausea and/or itching.

Studies also found differences in prescribing on personal basis. For example, in one study of a variety of chronic pain syndromes treated in a pain clinic it was found that pain severity, objective physical pathology, duration of pain, nor demographic factors had a major impact on prescribing of opioids. Rather, patients' behavioral manifestations of pain, distress, and suffering--pain behaviors-and, less often, reports of functional disability and distress, distinguished whether patients would be prescribed opioids.[15] Also, the literature showed that for persons who may not appear similar, ex. different racial backgrounds and ideological persuasions, can cause feelings of less empathy and altruistic motivation[13] which could influence prescribing attitudes. Some practitioners believed pain was exaggerated[6] and several studies suggested that racial differences may exist in receipt of adequate opioid analgesia. [14, 16, $17]$

Sickle cell disease (SCD) is an inherited hemoglobinopathy that causes intolerable acute pain, often morphing to chronic pain in adulthood, and early death. Doctors and nurses estimated high prevalence of addiction in patients with SCD. In one study by Shapiro, 53\% of ED physicians and $23 \%$ of hematologists felt that greater than $20 \%$ of adult patients with SCD were addicted to opioids. The same study showed that $22 \%$ of ED physicians and $9 \%$ of hematologists believed that more than $50 \%$ of the patients were addicted[18].

This opioid-phobia, fear of addiction, and under-prescription in SCD has sometimes led to friction between physicians and patients with acute exacerbations of SCD. For example, SCD patients often may be treated rudely, or experience delays in care, leading some to actually try to avoid the ED until extreme need provoked utilization.[19] We found that patients with SCD rated their satisfaction with care and the humaneness of their care significantly lower than did asthma patients. [20]

However, with the exception of cancer, less attention has been paid to the influence of disease type or source of pain stimulus on physicians' attitudes or practices regarding opioid prescription, apart from personal characteristics of their patients or the physicians[21]. Also, less attention has been paid to how physicians manage patients in urgent, acute pain, when those patients have a background of chronic pain. The current opioid epidemic is heightening such attention.

Therefore, in order to assess physician attitudes, knowledge, and experience related to management of acute-on-chronic non-cancer pain, in the late 1990s we developed and administered a questionnaire designed to differentiate between responses specific to three disease types. The focus of the survey, still extremely relevant today, was perspectives and attitudes of health care professionals in managing sickle cell disease pain compared to other chronic pain conditions.

\section{Methods}

\subsection{Study Measure}

A team of researchers, including one with experience in managing the pain of sickle cell disease and one with experience in scale construction, adapted parts of previously constructed questionnaires, [22, 23, 24, $25]$ to create a questionnaire for physicians assessing their perceptions of chronic pain management (Appendix). Three internal medicine fellows, as pilot participants, helped refine the questionnaire by providing feedback to the researchers after completing it. The questionnaire and all procedures used in this study were approved prior to use by the VCU Institutional Review Board.

Our questionnaire targeted residents who routinely rotate through the Emergency Department as part of their training, and therefore were routinely exposed to the scenarios presented. We assessed physician knowledge, experience, and attitudes related to chronic pain management in three different disease states. We chose these disease states--SCD, low back pain, and chronic pancreatitis-- because of our experience with SCD and our experience that caregivers express doubts about utilizing opioids for each of these conditions. The questionnaire was composed of four sections. First, we asked residents to consider three patient case scenarios. Each scenario similarly described a patient presenting to the emergency department seeking treatment for particularly painful episodic pain, but differed in the 
disease associated with the pain episode. Residents were asked to detail the prescriptions they would write to alleviate each patient's pain by indicating a medication, dose, and frequency. Residents were allowed to write up to three prescriptions per patient case scenario. Residents were also asked to estimate disease-specific population rates of opioid addiction, withdrawal, and severe complications. Second, we asked residents to indicate the extent to which they agreed or disagreed with a series of fourteen statements regarding their experience, knowledge, and attitudes related to chronic pain management in sickle cell disease, chronic low back pain, and chronic pancreatitis. Residents completed these items using a Likert scale that ranged from "strongly agree" (1) to "strongly disagree" (5). Third, we asked residents to rank, from most to least important, the sources of knowledge from which they drew to manage chronic pain. Finally, residents provided information regarding their gender, age and race, year of residency, internal medicine specialty, and medical school training.

\subsection{Data Collection}

Thirty-nine residents rotating on the internal medicine service at Medical College of Virginia Hospitals, a large urban teaching hospital located in Richmond, Virginia, affiliated with the Medical College of Virginia Campus of Virginia Commonwealth University (VCU), completed the questionnaire in the spring of 1997. Residents were approached by one of the researchers during a mandatory noon conference with the permission of the residency program director and asked to complete the questionnaire. Residents were told that their participation would provide valuable insight into many important issues surrounding chronic pain management and that their anonymity would be assured. All questionnaires were distributed, filled out, and collected within a fifteen-minute period during the noon conference. Respondents were instructed to make every effort to answer each question. No respondents approached the researcher with questions about ambiguous items. Throughout the survey, the thenpopular term "narcotic" was used instead of the current correct and more popular term, "opioid", but the terms carried essentially the same meaning. The term "non-malignant pain" was in use, rather than the current "non-cancer pain."

\subsection{Data Analysis}

Characteristics of all medical residents completing the questionnaire were determined using simple descriptive statistics, as was the knowledge source residents considered the most important to draw from when managing chronic pain.

Medication that residents most commonly prescribed to treat the severe pain described in each hypothetical case scenario was also determined using descriptive statistics. Residents could detail up to three prescriptions for each scenario, thus the total number of medications listed for each disease state exceeds the sample size of thirty-nine. Medications were coded according to their brand names.

Because responses to questions about disease-specific population rates of opioid addiction, withdrawal, and severe complications were not normally distributed, differences in these rates by disease state were examined using Friedman tests, nonparametric equivalents of a simple repeated measures analysis of variance, and Wilcoxon Rank-Sum tests, nonparametric equivalents of a two-related samples t-test. Differences in these rates by gender were examined using Wilcoxon Rank-Sum W (Mann-Whitney U) tests, nonparametric equivalents of a two-independent samples t-test. Differences in these rates by resident year were examined using Kruskal-Wallis $\mathrm{H}$ tests, nonparametric equivalents of a one-way analysis of variance, and Wilcoxon Rank-Sum W (Mann-Whitney U) tests.

Responses to Likert scale questions about residents' knowledge, experience, and attitudes regarding chronic pain management were also not normally distributed. Differences in these questions by disease state were examined using Friedman and Wilcoxon Rank-Sum tests. Differences in these questions by gender were examined using Wilcoxon Rank-Sum W (Mann-Whitney U) tests, and as were differences in these questions by resident year.

Spearman correlations were used to determine the relationship between residents estimated opioid addiction rates and experience, knowledge, and attitudes. All Likert scales for the questions regarding physician experience, knowledge, and attitudes were flipped and recoded to range from 1 (instead of 5) "strongly disagree" to 5 (instead of 1) "strongly agree" so that these correlations would make more intuitive sense to the reader. 


\section{$3 \quad$ Results}

\subsection{Study Participants}

Resident ages ranged from twenty-five to forty years, with a mean of twenty-nine years. Seventy-seven percent were male and twenty-one percent were female. Sixty-four percent were white, eighteen percent were Asian-American, and eight percent were of other racial backgrounds; ten percent of the residents did not indicate their race. Twenty-eight percent were first-year residents, thirty-one percent were second-year residents, and thirty-six percent were third-year residents. Fifty-four percent specialized in general internal medicine, eight percent in pulmonary/critical care, three percent in endocrinology, three percent in pediatrics, and three percent in psychiatry, while fifteen percent did not declare a specialty.

\subsection{Prescriptions to Alleviate Severe Pain}

Table 1 summarizes resident prescribing patterns for each patient case scenario. In total, residents prescribed eighteen different drugs for sickle cell disease pain, fifteen for chronic pancreatitis pain, and seventeen for chronic low back pain.

Table 1. Medications most commonly prescribed by medical residents to treat severe pain in hypothetical case scenarios, MCV/VCU, 1997

\begin{tabular}{|c|c|c|c|c|c|c|}
\hline \multirow{2}{*}{$\begin{array}{l}\text { Medications Prescribed } \\
\text { VISTARIL (Hydroxyzine) } 50 \\
\end{array}$} & \multicolumn{2}{|c|}{$\begin{array}{l}\text { Sickle Cell Disease } \\
\text { number } \& \text { percent }\end{array}$} & \multicolumn{2}{|c|}{$\begin{array}{l}\text { Chronic Pancreatitis } \\
\text { number } \& \text { percent }\end{array}$} & \multicolumn{2}{|c|}{$\begin{array}{l}\text { Chronic Low Back } \\
\text { Pain number \& percent }\end{array}$} \\
\hline & 2 & $2.7 \%$ & 2 & $3.0 \%$ & 0 & $0.0 \%$ \\
\hline IBUPROFEN (Advil)other & 1 & $1.4 \%$ & 1 & $1.5 \%$ & 9 & $12.3 \%$ \\
\hline MOTRIN (Ibuprofen) & 1 & $1.4 \%$ & 0 & $0.0 \%$ & 14 & $19.2 \%$ \\
\hline VISTARIL (Hydroxyzine) 25 & 1 & $1.4 \%$ & 4 & $6.0 \%$ & 0 & $0.0 \%$ \\
\hline TYLENOL(Acetaminophen) 325 & 1 & $1.4 \%$ & 0 & $0.0 \%$ & 11 & $15.1 \%$ \\
\hline PERCOCET (Oxycodone) & 17 & $23.0 \%$ & 9 & $13.4 \%$ & 7 & $9.6 \%$ \\
\hline TYLENOL (Acetaminophen)\#3 & 2 & $2.7 \%$ & 2 & $3.0 \%$ & 10 & $3.7 \%$ \\
\hline MORPHINE SULFATE (Roxanol) & 17 & $23.0 \%$ & 5 & $7.5 \%$ & 0 & $0.0 \%$ \\
\hline DEMEROL (Meperidine) & 10 & $13.5 \%$ & 25 & $37.3 \%$ & 0 & $0.0 \%$ \\
\hline MORPHINE other & 8 & $10.8 \%$ & 9 & $13.4 \%$ & 0 & $0.0 \%$ \\
\hline DILAUDID(Hydromorphone) & 5 & $6.8 \%$ & 1 & $1.5 \%$ & 0 & $0.0 \%$ \\
\hline $\begin{array}{l}\text { MS-CONTIN (Morphine sulfate } \\
\text { controlled-release) }\end{array}$ & 1 & $1.4 \%$ & 3 & $4.5 \%$ & 0 & $0.0 \%$ \\
\hline SUBLIMAZE (Fentanyl) & 3 & $4.1 \%$ & 1 & $1.5 \%$ & 0 & $0.0 \%$ \\
\hline
\end{tabular}

a Residents could detail up to three prescriptions for each scenario, thus the total number of prescriptions for each disease state listed in the table exceeds the sample size of thirty-nine.

\subsection{Perceived Rates of Opioid Addiction, Withdrawal, and Severe Complication}

Table 2 presents the mean estimated population rates of opioid addiction, withdrawal, and severe complication by disease as reported by the residents. Resident estimates of the rate of opioid addiction in sickle cell disease were higher than estimates in both chronic pancreatitis and chronic low back pain. Overall comparisons using the Friedman test showed significant differences among estimates for the three disease states. Paired comparisons using the Wilcoxon Rank-Sum test revealed statistically significant differences between rate estimates in sickle cell disease and chronic low back pain and between rate estimates in chronic pancreatitis and chronic low back pain, while differences between rate estimates in sickle cell disease and chronic pancreatitis were not significant. Resident estimates of the rate of withdrawal symptoms in sickle cell disease were also higher than estimates in both chronic pancreatitis and chronic low back pain. Again, overall comparisons using the Friedman test showed significant differences among estimates for the three disease states. Paired comparisons using the 
Wilcoxon Rank-Sum test revealed statistically significant differences between rate estimates in sickle cell disease and chronic low back pain and between rate estimates in chronic pancreatitis and chronic low back pain, while differences between rate estimates in sickle cell disease and chronic pancreatitis were not significant. Resident estimates of severe complication rates for sickle cell disease were slightly less than estimates for chronic pancreatitis and greater than that for chronic back pain, but no statistically significant differences were found.

Table 2. Estimated rates of opioid addiction, withdrawal, and severe complication by residents $(\mathrm{N}=39)$, VCU, 1997

\begin{tabular}{l|c|c|c}
\hline & $\begin{array}{c}\text { Sickle Cell Disease } \\
\text { mean } \pm \mathrm{SD}\end{array}$ & $\begin{array}{c}\text { Chronic Pancreatitis } \\
\text { mean } \pm \mathrm{SD}\end{array}$ & $\begin{array}{c}\text { Chronic Low Back Pain } \\
\text { mean } \pm \mathrm{SD}\end{array}$ \\
\hline Addiction $^{\mathrm{a}}$ & $43.1 \pm 26.3^{\mathrm{b}}$ & $37.0 \pm 27.7^{\mathrm{c}}$ & $28.3 \pm 22.9$ \\
\hline Withdrawal $^{\mathrm{a}}$ & $27.8 \pm 24.6^{\mathrm{b}}$ & $25.8 \pm 27.1^{\mathrm{c}}$ & $17.3 \pm 21.4$ \\
\hline Severe Complications $^{\mathrm{c}}$ & $12.8 \pm 17.0$ & $13.0 \pm 16.4$ & $9.1 \pm 11.6$ \\
\hline
\end{tabular}

${ }^{\mathrm{a}}$ significance level of difference $\mathrm{p}<.01$ using Friedman test, comparing all three disease states

${ }^{\mathrm{b}}$ significance level of difference $\mathrm{p}<.05$ using Wilxocon Rank-Sum test, comparing sickle cell disease with chronic low back pain

${ }^{\mathrm{c}}$ significance level of difference $\mathrm{p}<.05$ using Wilcoxon Rank-Sum test, comparing chronic pancreatitis with chronic low back pain

Female residents consistently estimated rates of opioid addiction higher than male residents, though the only statistically significant difference found between the two groups was for rate estimates in chronic low back pain (Table 3). Female residents also consistently estimated withdrawal rates higher than male residents, but their estimates of severe complication rates were consistently lower than males'. No statistically significant differences were found between males and females for opioid withdrawal and severe complication rates.

Table 3. Estimated rates of opioid addiction, withdrawal, and severe complication by resident gender $(\mathrm{N}=39)$, $\mathrm{MCV} / \mathrm{VCU}, 1997$

\begin{tabular}{l|c|c}
\hline & $\begin{array}{c}\text { Females } \\
\mathrm{n}=8 \\
\text { mean } \pm \mathrm{SD}\end{array}$ & $\begin{array}{c}\text { Males } \\
\mathrm{n}=30 \\
\text { mean } \pm \mathrm{SD}\end{array}$ \\
\hline Addiction & & \\
\hline sickle cell disease & $48.8 \pm 30.1$ & $21.1 \pm 25.9$ \\
\hline chronic low back pain & $43.9 \pm 30.0$ a & $32.5 \pm 25.4$ \\
\hline chronic pancreatitis & $51.6 \pm 33.5$ & \\
\hline Withdrawal & & $25.9 \pm 24.3$ \\
\hline sickle cell disease & $34.1 \pm 27.8$ & $14.4 \pm 20.1$ \\
\hline chronic low back pain & $22.5 \pm 21.7$ & $21.4 \pm 23.8$ \\
\hline chronic pancreatitis & $41.3 \pm 35.4$ & \\
\hline Severe Complications & & $13.9 \pm 18.3$ \\
\hline sickle cell disease & $8.9 \pm 13.2$ & $8.5 \pm 11.1$ \\
\hline chronic low back pain & $7.4 \pm$ & 8.4 \\
\hline chronic pancreatitis & $10.9 \pm 12.4$ & $13.6 \pm 17.8$ \\
\hline
\end{tabular}

${ }^{a}$ significance level of difference $\mathrm{p}<.05$ using Mann-Whitney U test, comparing males and females

Second-year residents generally estimated rates of opioid addiction and severe complications higher than first- and third-year residents, while third-year residents estimated rates of withdrawal symptoms higher than first- and second-year residents. No statistically significant differences were found when the three groups were compared. 


\subsection{Residents' Knowledge, Experience, and Attitudes about Chronic Pain}

Most residents $(53.8 \%)$ described their personal clinical experience as the most important driver of pain management decisions, rather than others' clinical experience, their education, or objective sources of knowledge.

Table 4 outlines the median responses to the Likert scale questions regarding residents' knowledge, experience, and attitudes about chronic pain management. Few statistically significant differences in these responses were noted when compared by disease state. Responses to "I am confident about my knowledge of narcotic pharmacokinetics as it relates to this disease" only differed significantly between chronic pancreatitis and chronic low back pain. Overall comparisons of responses to "The pain episodes of most patients within this population are treated at home" showed significant differences among the three disease states, while paired comparisons only revealed statistically significant differences between responses for sickle cell disease and chronic pancreatitis and between responses for sickle cell disease and chronic low back pain. Overall comparisons of responses to "I have had extensive experience treating patients like these" also showed significant differences among the three disease states, though paired comparisons only revealed statistically significant differences between responses for sickle cell disease and chronic low back pain. Responses to "When managing pain in this population, my goal is to completely alleviate the patients' pain" differed significantly between sickle cell disease and chronic low back pain.

Table 4. Resident knowledge, experience, and attitudes regarding chronic pain management a, MCV/VCU, 1997 (mean)

\begin{tabular}{|c|c|c|c|}
\hline & $\begin{array}{c}\text { Sickle Cell } \\
\text { Disease } \\
\text { mean }\end{array}$ & $\begin{array}{c}\text { Chronic } \\
\text { Pancreatitis } \\
\text { mean }\end{array}$ & $\begin{array}{c}\text { Chronic Low } \\
\text { Back Pain } \\
\text { mean }\end{array}$ \\
\hline \multicolumn{4}{|l|}{ Knowledge } \\
\hline $\begin{array}{l}\text { I feel that I have had adequate training in the pain } \\
\text { management of these patients. }\end{array}$ & 3.1 & 3.2 & 3.5 \\
\hline $\begin{array}{l}\text { I am confident about my knowledge of narcotic } \\
\text { pharmacokinetics as it relates to this disease. }\end{array}$ & 3.1 & $3.2^{\mathrm{e}}$ & 3.2 \\
\hline $\begin{array}{l}\text { Patients presenting in the emergency department are } \\
\text { well representative of the entire population. }\end{array}$ & 4.2 & 4.2 & 4.1 \\
\hline $\begin{array}{l}\text { The pain episodes of most patients within this } \\
\text { population are treated at home. }{ }^{\mathrm{b}}\end{array}$ & $3.2^{\mathrm{d}}$ & 3.4 & 2.2 \\
\hline \multicolumn{4}{|l|}{ Experience } \\
\hline $\begin{array}{l}\text { I have had extensive experience treating patients like } \\
\text { these. }^{c}\end{array}$ & $2.6^{\mathrm{e}}$ & 2.7 & 3.1 \\
\hline $\begin{array}{l}\text { Most of my experience with patients like these has } \\
\text { been in the emergency department. }\end{array}$ & 3.0 & 3.1 & 3.2 \\
\hline \multicolumn{4}{|l|}{ Attitude } \\
\hline $\begin{array}{l}\text { I worry about the possibility of addiction when } \\
\text { treating patients with this disease. }\end{array}$ & 2.4 & 2.3 & 2.4 \\
\hline $\begin{array}{l}\text { I feel that patients in this population are at a higher } \\
\text { risk of addiction than other pain patients. }\end{array}$ & 2.6 & 2.6 & 2.7 \\
\hline $\begin{array}{l}\text { These patients will sometimes lie about pain just to } \\
\text { get drugs. }\end{array}$ & 2.4 & 2.3 & 2.5 \\
\hline $\begin{array}{l}\text { When managing pain in this population, my goal is } \\
\text { to completely alleviate the patient's pain. }\end{array}$ & $2.4^{\mathrm{d}}$ & 2.6 & 2.7 \\
\hline $\begin{array}{l}\text { Patients in this population are adequately medicated } \\
\text { for their pain. }\end{array}$ & 3.2 & 3.2 & 3.4 \\
\hline $\begin{array}{l}\text { Patients in this population seeking treatment for } \\
\text { pain ask for too many drugs. }\end{array}$ & 3.1 & 2.9 & 2.9 \\
\hline
\end{tabular}




\begin{tabular}{l|c|c|c}
\hline $\begin{array}{l}\text { I sometimes doubt that these patients' pain episodes } \\
\text { are genuine. }\end{array}$ & 2.7 & 2.5 & 2.6 \\
\hline $\begin{array}{l}\text { I frequently monitor patients under my care to see if } \\
\text { they need anything for their pain. }\end{array}$ & 2.4 & 2.5 & 2.4 \\
\hline
\end{tabular}

${ }^{\text {a }}$ Responses to Likert scale questions ranged from 1 (strongly agree) to 5 (strongly disagree)

${ }^{\mathrm{b}}$ significance level of difference $\mathrm{p}<.01$ using Friedman test

${ }^{c}$ significance level of difference $\mathrm{p}<.05$ using Friedman test

${ }^{\mathrm{d}}$ significance level of difference $\mathrm{p}<.01$ using Wilcoxon Rank-Sum test

${ }^{\mathrm{e}}$ significance level of difference $\mathrm{p}<.05$ using Wilcoxon Rank-Sum test

Male and female residents differed on only one question, "I worry about the possibility of addiction when treating patients with this disease," in chronic low back pain $(\mathrm{p}=.03)$, sickle cell disease ( $\mathrm{p}$ $=.07)$, and chronic pancreatitis $(\mathrm{p}=.10)$. No other significant differences were observed.

Several differences were observed when responses were compared by year of residency. First, responses to "I am confident about my knowledge of narcotic pharmacokinetics as it relates to this disease" differed between first- and second-year residents $(\mathrm{p}<.05)$ and between first- and third-year residents $(\mathrm{p}$ $<.01)$ in all three disease states. No significant differences between second- and third-year residents were observed. Second, responses to "I have had extensive experience treating patients with problems like this" differed between first- and second-year residents in chronic pancreatitis $(\mathrm{p}<.01)$ and chronic low back pain $(\mathrm{p}<.05)$ and between first- and third-year residents in all three disease states $(\mathrm{p}<.05)$. No significant differences were observed between second- and third-year residents. Third, responses to "These patients will sometimes lie about pain just to get drugs" differed between first- and second-year residents in chronic pancreatitis $(\mathrm{p}<.01)$ and between first- and third-year residents in both sickle cell disease and chronic pancreatitis $(\mathrm{p}<.01)$. No significant differences were observed between second- and third-year residents. Finally, responses to "I sometimes doubt that these patients' pain episodes are genuine" differed between first- and third-year residents in chronic pancreatitis $(\mathrm{p}<.01)$ and chronic low back pain $(\mathrm{p}<.05)$ and between second- and third-year residents in sickle cell disease $(\mathrm{p}<.05)$ and chronic pancreatitis $(\mathrm{p}<.01)$. No significant differences were observed between first- and second-year residents.

\subsection{Opioid Addiction and Residents' Experience, Knowledge and Attitudes}

Few significant correlations between estimated opioid addiction rates and residents' experience, knowledge, and attitudes regarding chronic pain management were observed (Table 5). Perceived rates of opioid addiction correlated with concerns about addiction, but, otherwise, correlated with little else.

Table 5. Correlations between resident estimates of opioid addiction rates and resident experience, knowledge, and attitudes regarding chronic pain management.

\begin{tabular}{l|c|c|c}
\hline & \multicolumn{2}{|c}{ Estimated Aaaiction Rates } \\
\hline & $\begin{array}{c}\text { Sickle Cell } \\
\text { Disease }\end{array}$ & $\begin{array}{c}\text { Chronic } \\
\text { Pancreatitis }\end{array}$ & $\begin{array}{c}\text { Chronic Low } \\
\text { Back Pain }\end{array}$ \\
\hline Knowledge & & & \\
\hline $\begin{array}{l}\text { I feel that I have had adequate training in the pain } \\
\text { management of these patients. }\end{array}$ & 0.13 & 0.30 & 0.13 \\
\hline $\begin{array}{l}\text { I am confident about my knowledge of narcotic } \\
\text { pharmacokinetics as it relates to this disease. }\end{array}$ & 0.02 & -0.07 & 0.09 \\
\hline $\begin{array}{l}\text { Patients presenting in the emergency department are well } \\
\text { representative of the entire population. }\end{array}$ & -0.26 & -0.19 & $-0.33 \mathrm{~b}$ \\
\hline $\begin{array}{l}\text { The pain episodes of most patients within this population } \\
\text { are treated at home. }\end{array}$ & 0.11 & -0.02 & 0.09 \\
\hline \begin{tabular}{l} 
Experience \\
\hline
\end{tabular}
\end{tabular}




\begin{tabular}{|c|c|c|c|}
\hline I have had extensive experience treating patients like these. & 0.07 & 0.04 & $0.34^{\mathrm{b}}$ \\
\hline $\begin{array}{l}\text { Most of my experience with patients like these has been in } \\
\text { the emergency department. }\end{array}$ & 0.14 & 0.05 & 0.08 \\
\hline \multicolumn{4}{|l|}{ Attitude } \\
\hline $\begin{array}{l}\text { I worry about the possibility of addiction when treating } \\
\text { patients with this disease. }\end{array}$ & 0.13 & -0.25 & $-0.42^{a}$ \\
\hline $\begin{array}{l}\text { I feel that patients in this population are at a higher risk of } \\
\text { addiction than other pain patients. }\end{array}$ & $-0.41^{\mathrm{a}}$ & $-0.43^{a}$ & $-0.47^{a}$ \\
\hline $\begin{array}{l}\text { These patients will sometimes lie about pain just to get } \\
\text { drugs. }\end{array}$ & -0.16 & -0.22 & $-0.38^{b}$ \\
\hline $\begin{array}{l}\text { When managing pain in this population, my goal is to } \\
\text { completely alleviate the patient's pain. }\end{array}$ & -0.06 & 0.08 & 0.08 \\
\hline $\begin{array}{l}\text { Patients in this population are adequately medicated for } \\
\text { their pain. }\end{array}$ & -0.24 & 0.12 & $-0.34^{b}$ \\
\hline $\begin{array}{l}\text { Patients in this population seeking treatment for pain ask } \\
\text { for too many drugs. }\end{array}$ & -0.18 & 0.03 & -0.26 \\
\hline $\begin{array}{l}\text { I sometimes doubt that these patients' pain episodes are } \\
\text { genuine. }\end{array}$ & -0.30 & -0.31 & -0.31 \\
\hline $\begin{array}{l}\text { I frequently monitor patients under my care to see if they } \\
\text { need anything for their pain. }\end{array}$ & -0.14 & -0.20 & 0.01 \\
\hline
\end{tabular}

${ }^{\mathrm{a}}$ significance $\mathrm{p}<.01$ for Spearman correlations

${ }^{\mathrm{b}}$ significance $\mathrm{p}<.05$ for Spearman correlations

\section{Discussion}

We hypothesized that caregivers would under-medicate sickle cell disease patients more than low back pain and chronic pancreatitis patients. Our hypothesis was based on research suggesting multiple, perhaps additive effects that would differentially temper use of opioids in these hypothetical patients.

Sickle cell patients might show no objective pathology justifying opioids in the provider's judgment. But the same might perhaps be true for low back pain patients and chronic pancreatitis patients. Possibly, sickle cell disease patients might not display negative affective behavior during painful episodes. But again, the same might be true for low back pain and chronic pancreatitis patients. However, based on prior research, sickle cell disease patients, who in the U.S. are nearly all African-American, might receive less analgesia than racial majority members, and might more often be suspected of malingering, of being dependent on opioids, or of being psychologically addicted than those with the "control" conditions.[26]

We found that both estimated rates of opioid addiction (defined by the caregiver) and estimated rates of withdrawal symptoms were consistently higher for either sickle cell disease patients or chronic pancreatitis patients than for low back pain patients. However, these rates were not estimated statistically significantly higher for sickle cell disease patients than for chronic pancreatitis patients, though numeric estimates were higher for sickle cell disease patients.

We found numeric but not statistical differences in the estimates of disease complications for the three conditions. Though perhaps caregivers did indeed judge differences in biologic severity of the three diseases, these differences were not judged as significant using the gross severity scale we provided.

We hypothesized and found nearly no gender differences or differences in training by year of residency in estimations of addiction and opioid withdrawal. Sjostrom and colleagues found experience differences by nurses, e.g., those with more experience were more opioid-phobic or rated pain less.

We found that most residents described their personal clinical experience as the most important when drawing from sources of knowledge to manage chronic pain, and did not report differential knowledge by disease state.

Our results compare with those of other researchers studying physicians' judgment about pain. Tearnan and Dar[27] gave a questionnaire to a large sample of staff physicians and residents $(\mathrm{n}=193)$, 
asking them to rate 10 pain descriptors for level of applicability to 4 common acute and chronic pain syndromes. Physicians agreed on the ratings of the descriptors within pain syndromes, and rated descriptors in a way that discriminated between pain syndromes. Ratings were not affected by specialty training, experience with pain patients, or amount of specialized training in pain. Physicians with more training in pain, however, considered the diagnostic utility of pain descriptors higher. For all physicians, the diagnostic utility of pain descriptors was rated higher for acute than for chronic pain. Acute pain was rated by physicians as more painful and more interfering with mood and physical activity.

Guru and Dubinsky[28] surveyed emergency department caregivers and patients in a tertiary care teaching hospital, asking them to rate patients' pain on arrival to the ED. Both physicians and nurses gave statistically significantly lower pain ratings than did patients. Nurses' ratings were lower than physicians' ratings of the same patients. On chart review, no pain scale assessments were employed, and only one chart noted that a patient's pain had been relieved after treatment. Approximately half the patients felt on discharge from the ED that their pain had not been relieved.

While we found no differences by year of training in estimations of addiction or withdrawal, Sjostrom and colleagues[29] did. They described strategies used by experienced and less experienced nurses and physicians in their assessment of postoperative pain and related different approaches, clinical experience, and professional role to the accuracy of the pain ratings. Commonly used strategies in the pain assessment were: -how the patient looks, -what the patient says, -the manner of talking, and -past experience of similar circumstances. The mean score given by the patients was significantly higher than that rated by the staff members. Nurses as well as physicians overestimated low and underestimated high levels of pain indicated by the patients. The accuracy of nurse ratings, especially more experienced ones, was less precise than that of physicians, and showed systematic underestimation.

Loveman and Gale, [30] using vignettes which varied four variables, examined the factors that influence nurses' perception of patient pain. Mobility and positive signs of pain had statistically significant effects on nurses' judgments of inferred pain, but diagnosis had no main effect. Significant interactions showed that: inferred pain in male patients was seen to be greater when immobile while mobility had no effect on the inferred pain of female patients; oncology patients (compared with surgical patients) had greater inferred pain when displaying positive signs; and positive signs yielded higher ratings where patients were immobile. Female patients were perceived to experience higher psychological distress than men and oncology patients were perceived to experience higher distress than surgical patients. Ratings of perceived pain and distress were significantly correlated but did not differ in magnitude. Offered a choice of analgesics to relieve pain for each of the patients depicted, nurses typically chose those with the lowest strength.

Todd and colleagues[31] sought to determine whether physician estimates of acute long bone pain severity were influenced by patient ethnicity. Though there were disparities between physician-measured vs. patient-measured pain, there were no differences between non-Hispanic white and Hispanic patients in patient pain assessments, physician pain assessments, or the disparity between patient and physician pain assessments. The degree of disparity between patient and physician pain assessments remained similar for both groups even after controlling for multiple potential confounders. Physical attractiveness may influence caregivers' pain ratings or judgment about the need for analgesia[32].

A review of research[33] on the use of opioids for chronic non-cancer pain found no controlled studies of patients with low back pain. Case series reports on a total of 566 patients suggested that chronic opioids was safe and effective for many patients with recalcitrant chronic low back pain who respond inadequately to other treatments. But preexisting substance use disorders, personality disorders, certain medical conditions, and certain occupational factors were relative contraindications to chronic opioid use.

Prescribing opioids for patients with chronic non-cancer pain (CNCP) is controversial. Part of the current opioid epidemic is being attributed to the $14.6 \%$ rate of $\mathrm{CNCP}$ and the challenge of managing it safely. [34] But part is also being blamed on the "war on chronic pain" using more aggressive pain assessment and more opioids, supported by JCAHO [ref pain as fifth vital sign], and waged by pharmaceutical companies [ref Purdue Pharma], and some medical authorities [35]

The war began with suggestions that selected chronic pain patients with CNCP could be prescribed more opioids over time without significant ill effects, $[35,35,36,37,38,39]$ though a review of the evidence supporting this practice deemed it equivocal,[40] and patient opinion was mixed in one study of recipients of this therapy[41]. Nonetheless, a then-contemporary survey of over 6,000 physicians from multiple states found that prescription of long-term opioids for non-malignant pain was relatively wide- 
spread [42]. Differences were noted in this survey by region, specialty, and the legal requirement for the use of multiple prescriptions for schedule II drugs. These influences were noted in other studies to describe or influence prescribing of opioids for pain $[43,44,45,46]$.

The war on chronic pain spilled over to SCD. Writers of a guideline ca. 1990s for pain management in SCD revealed the many issues surrounding prescribing opioids for SCD patients, and advocated for a more liberal use of opioids[47, 48]. They found a low range of quoted incidences of addiction, from $0 \%$ to 11\%. Brozovic reported that among 101 patients with SCD in England, 3 patients were "addicted" to drugs whereas another 7 patients were "drug dependent."[49] Vichinsky, Johnson, and Lubin reported an intervention to reduce utilization, during which no incidence of "drug addiction" was seen among 600 patients with SCD[50] However, in both of these studies it was unclear exactly what was meant by the terms "addiction" and "dependence."

Now, armed with the CDC evidence, experts have backed off some prior claims[ref news article Portnoy, pain expert, reverses opinion], and have acknowledged the unintended consequences of the war. Academic societies, the CDC[47], and states have sought to reduce the dose of long-term opioid therapy, or prevent dose escalation, with some success in reducing use in NY, TN, [48] and FL. [51], but mostly ineffective.[52] Also, administrative restrictions have generated claims of lowered access for needy patients or eroded bilateral trust.[53]

In our experience and in that of others, patients with $\mathrm{CNCP}$ managed with opioids may be expected to develop tolerance and even physical dependence over time, but not the aberrant behaviors, including rapid dose escalation, associated with psychological addiction or drug seeking for profit $[54,55,56]$. No mood and/or cognitive deficits occurred post-therapy in at least one study of non-cancer pain patients, as compared to controls - in fact, medication reduced anxiety and hostility[57]. In another study of low back pain patients, opioid therapy was used without significant risk of abuse, had a positive effect on pain and mood, and little effect on activity and sleep[58].

Limitations of our study include low generalizability in that it was conducted two decades ago in a single institution with a small sample size, in an area with relatively high prevalence of SCD, like other states on the eastern seaboard, vs the western mountain states, Vermont, etc.[59] Physician attitudes about SCD versus other chronic diseases in today's climate, in other residents in our institution, in other institutions, or in low-prevalence areas could vary.

We conclude that this survey research, performed before the current opioid epidemic, shows that predating the current opioid epidemic there was both a backdrop of opioid-phobia and a bias against treating SCD pain compared to other chronic pain conditions among our sample. Repeating this survey research among current training physicians, along with surveys of other attitudes, would provide useful comparisons.

\section{References}

1. Rudd RA, Aleshire N, Zibbell JE, Gladden RM. Increases in Drug and Opioid Overdose Deaths--United States, 2000-2014. MMWR Morb Mortal Wkly Rep. 2016 Jan 1; 64(50-51):1378-82.

2. Opioid Painkiller Prescribing, Where You Live Makes a Difference. Centers for Disease Control and Prevention. Available at http://www.cdc.gov/vitalsigns/opioid-prescribing/. Published July 2014. Assessed September 12, 2016.

3. Paulozzi LJ, Strickler GK, Kreiner PW, Koris CM. Controlled Substance Prescribing Patterns - Prescription Behavior Surveillance System, Eight States, 2013. MMWR Surveill Summ. 2015 Oct 16;64(9):1-14.

4. Marks RM, Sachar EJ. Undertreatment of medical inpatients with narcotic analgesics. Ann Intern Med 1973; 78(2): 173-181.

5. Taylor AG, Skelton JA, Butcher J. Duration of pain condition and physical pathology as determinants of nurses' assessments of patients in pain. Nurs Res 1984; 33(1): 4-8.

6. Taylor AG, Skelton JA, Butcher J. Duration of pain condition and physical pathology as determinants of nurses' assessments of patients in pain. Nurs Res 1984; 33(1): 4-8.

7. Tait RC, Chibnall JT. Physician judgments of chronic pain patients. Soc Sci Med 1997; 45(8):1199-1205.

8. Nguyen RHN, Turner RM, Rydell SA, Maclehose RF, Harlow BL. Perceived stereotyping and seeking care for chronic vulvar pain. Pain Med 2013;14(10):1461-1467. 
9. Hill CS Jr. The barriers to adequate pain management with opioid analgesics. Semin Oncol 1993; 20 (2 Suppl $1): 1-5$.

10.Stiefel F, Morant R, Radziwill A, Senn HJ. Attitudes of Swiss physicians in prescribing opiates for cancer pain. Support Care Cancer 1993;1(5): 259-262.

11.Morrison RS, Wallenstein S, Natale DK, Senzel RS, Huang LL. "We don't carry that"--failure of pharmacies in predominantly nonwhite neighborhoods to stock opioid analgesics. N Engl J Med 2000; 342(14):1023-1026.

12.Greenwald BD, Narcessian EJ. Opioids for managing patients with chronic pain: community pharmacists' perspectives and concerns. J Pain Symptom Manage 1999;17(5): 369-375.

13.De Ruddere L, Craig KD. Understanding stigma and chronic pain: a state of the art review. Pain. 2016;157(8): $1607-1610$

14.Ng B, Dimsdale JE, Shragg GP, Deutsch R. Ethnic differences in analgesic consumption for postoperative pain. Psychosom Med 1996; 58(2):125-129

15.Turk DC, Okifuji A. What factors affect physicians' decisions to prescribe opioids for chronic noncancer pain patients? Clin J Pain 1997;13(4): 330-336

16. Todd KH, Samaroo N, Hoffman JR. Ethnicity as a risk factor for inadequate emergency department analgesia. JAMA 1993; 269(12):1537-1539.

17.Cleeland CS, Gonin R, Baez L, Loehrer P, Pandya KJ. Pain and treatment of pain in minority patients with cancer. The eastern cooperative oncology group minority outpatient pain study. Ann Intern Med 1997;127(9): 813-816.

18.Barbara S. Shapiro, Lennette J. Benjamin, Richard Payne, George Heidrich, Sickle cell-related pain: Perceptions of medical practitioners, Journal of Pain and Symptom Management, Volume 14, Issue 3, 1997, Pages 168-174, ISSN 0885-3924, http://dx.doi.org/10.1016/S0885-3924(97)00019-5. （http://www.sciencedirect.com/science/ article/pii/S0885392497000195)

19.Murray N, et al. Painful crises in sickle cell disease--patients' perspectives. BMJ 1988. Aug 13;297(6646):452-4.

20.Bobo L, Miller ST, Smith WR, Elam JT, Rosmarin PC, Lancaster DJ. Health perceptions and medical care opinions of inner-city adults with sickle cell disease and asthma compared with their siblings. South Med J 82:9$12,1989$.

21.Lucchesi F, Figueiredo MS, Mastandrea EB, Levenson JL, Smith WR, Jacinto AF, Citero VA, Physicians' perception of sickle-cell disease pain, J National Med Assoc, 2016; 108(2): 113-118.

22. Charap AD. The knowledge, attitudes, and experience of medical personnel treating pain in the terminally ill. Mount Sinai J Med 1978; 45(4): 561-580.

23.Alleyne $\mathrm{J}$ and Thomas VJ. The management of sickle cell crisis pain as experienced by patients and their carers. J Adv Nurs 1994; 19(4): 725-732.

24.Waldrop RD and Mandry C. Health professional perceptions of opioid dependence among patients with pain. Am J Emerg Med 1995; 13(5): 529-531.

25.Waters J and Thomas V. Pain from sickle-cell crisis. Nurs Times 1995; 91(16): 29-31.

26.Jenerette CM, Brewer C. Health-related stigma in young adults with sickle cell disease. J National Med Assoc. 2010;102(11):1050-1055.

27.Tearnan BH, Dar R. Physician ratings of pain descriptors: potential diagnostic utility. Pain 1986; 26(1): 45-51.

28.Guru V, Dubinsky I. The patient vs. caregiver perception of acute pain in the emergency department. J Emerg Med 2000;18(1): 7-12.

29.Sjostrom B, Haljamae H, Dahlgren LO, Lindstrom B. Assessment of postoperative pain: impact of clinical experience and professional role. Acta Anaesthesiol Scand 1997;41(3):339-44.

30.Loveman E, Gale A. Factors influencing nurses' inferences about patient pain. Br J Nurs 2000; 9(6): 334-337.

31.Todd KH, Lee T, Hoffman JR. The effect of ethnicity on physician estimates of pain severity in patients with isolated extremity trauma. JAMA 1994; 271(12): 925-928.

32.Hadjistavropoulos HD, Ross MA, von Baeyer CL Are physicians' ratings of pain affected by patients' physical attractiveness? Soc Sci Med 1990; 31(1): 69-72.

33.Brown RL, Fleming MF, Patterson JJ. Chronic opioid analgesic therapy for chronic low back pain. J Am Board Fam Pract 1996; 9(3): 191-204.

34.Nahin RL. Estimates of pain prevalence and severity in adults: United States, 2012. J Pain 2015; 16:769-80. 
35.Portenoy RK. Opioid therapy for chronic nonmalignant pain: a review of the critical issues. J Pain Symptom Manage 1996; 11(4): 203-17.

36.Schug SA, Merry AF, Acland RH. Treatment principles for the use of opioids in pain of nonmalignant origin. Drugs 1991; 42(2): 228-39.

37.Jamison RN. Comprehensive pretreatment and outcome assessment for chronic opioid therapy in nonmalignant pain. J Pain Symptom Manage 1996; 11(4): 231-41.

38.Schofferman J. Long-term use of opioid analgesics for the treatment of chronic pain of nonmalignant origin. J Pain Symptom Manage 1993; 8(5): 279-88.

39. Conigliaro DA. Opioids for chronic non-malignant pain. J Fla Med Assoc 1996; 83(10): 708-711.

40.Turk DC. Clinicians' attitudes about prolonged use of opioids and the issue of patient heterogeneity. J Pain Symptom Manage 1996; 11(4): 218-230.

41.Jamison RN, Anderson KO, Peeters-Asdourian C, Ferrante FM. Survey of opioid use in chronic nonmalignant pain patients. Reg Anesth 1994;19(4): 225-230.

42.Turk DC, Brody MC, Okifuji EA. Physicians' attitudes and practices regarding the long-term prescribing of opioids for non-cancer pain. Pain 1994; 59(2): 201-208.

43. Weinstein SM, Laux LF, Thornby JI, Lorimor RJ, Hill CS Jr, Thorpe DM, Merrill JM. Physicians' attitudes toward pain and the use of opioid analgesics: results of a survey from the Texas Cancer Pain Initiative. South Med J 2000; 93(5): 479-487.

44.Clark HW, Sees KL. Opioids, chronic pain, and the law. J Pain Symptom Manage 1993; 8(5): 297-305.

45.McQuay H. Opioids in pain management. Lancet 1999; 353(9171): 2229-2232.

46.Savage SR. Long-term opioid therapy: assessment of consequences and risks. J Pain Symptom Manage 1996;11(5): 274-286.

47.Dowell D, Haegerich TM, Chou R. CDC Guideline for Prescribing Opioids for Chronic Pain--United States, 2016. JAMA. 2016 Apr 19; 315(15):1624-45.

48.Vital Signs Morbidity and Mortality Weekly Report, July 1, 2014; MA: Declines in Opioid Prescribing After a Private Insurer Policy Change - Massachusetts, 2011-2015. MMWR Weekly / October 21, 2016 / 65(41);11251131.

49.Brozovic, M., Davies, S. C., Yardumian, A., Bellingham, A.,Marsh, G., \& Stephens, A. D. (1986). Pain relief in sicklecell crises (letter). Lancet, 2, 624-625.

50.Vichinsky, E., Lubin, B. H. (1987). Suggested guidelines for the treatment of children with sickle cell anemia. Hematology/Oncology Clinics of North America, , 1, 483-501.

51.PDMP Center of Excellence at Brandeis University, 2014.

52.Nuckols TK, Anderson L, Popescu I, et al. Opioid Prescribing: A Systematic Review and Critical Appraisal of Guidelines for Chronic Pain. Ann Intern Med. 2014; 160: 38-47.

53.Lanzkron, S. Opioid Backlash Threatens Sickle Cell Care. Physicians Weekly, Dec 19, 2013; http://dev. physiciansweekly.com/sickle-cell-opioids-backlash/ ; Accessed by Wally R. Smith on Oct 30, 2016.

54.Sees KL, Clark HW. Opioid use in the treatment of chronic pain: assessment of addiction. J Pain Symptom Manage 1993; 8(5): 257-264.

55.Tennant F Jr, Robinson D, Sagherian A, Seecof R. Chronic opioid treatment of intractable, non-malignant pain. NIDA Res Monogr 1988; 81:174-180.

56.Ytterberg SR, Mahowald ML, Woods SR Codeine and oxycodone use in patients with chronic rheumatic disease pain. Arthritis Rheum 1998; 41(9):1603-1612.

57.Haythornthwaite JA, Menefee LA, Quatrano-Piacentini AL, Pappagallo M. Outcome of chronic opioid therapy for non-cancer pain. J Pain Symptom Manage 1998;15(3):185-194.

58.Jamison RN, Raymond SA, Slawsby EA, Nedeljkovic SS, Katz NP, Opioid therapy for chronic noncancer back pain. A randomized prospective study. Spine 1998; 23(23): 2591-2600.

59.Hassell KL. Population estimates of sickle cell disease in the U.S. Am J Prev Med. 2010 Apr;38(4 Suppl):S512-21. doi: 10.1016/j.amepre.2009.12.022. PubMed PMID: 20331952. 


\section{Appendix: Physician Survey}

Thank you for taking a moment to complete this short survey. Please make every effort to answer each question and not to leave anything blank. Your responses will provide invaluable insight into many important issues surrounding chronic pain management. Thank You!

First, consider the following patient case scenarios. Each patient presents to you in the emergency department seeking treatment for particularly painful episodic pain. Though these particularly painful episodes occur only once per year, each reports less painful episodes of two to three days per month which they are able to manage at home using opioid analgesia. All patients are 150 pound black males. Please answer the following questions according to these case scenarios.

Patient is disabled secondary to Chronic Low Back Pain associated with a work related injury and is complaining of a recurrence of his typical pain.
Patient is characterized as having Sickle Cell Disease and is in the midst of a painful sickle cell episode.
Patient is an alcoholic man diagnosed with Chronic

Pancreatitis complaining of his typical pancreatitis pain after an ethanol binge.

How would you treat this man's pain? Please detail your prescription (or prescriptions) for each patient in the space provided below. Include medication, dose, and frequency for each.

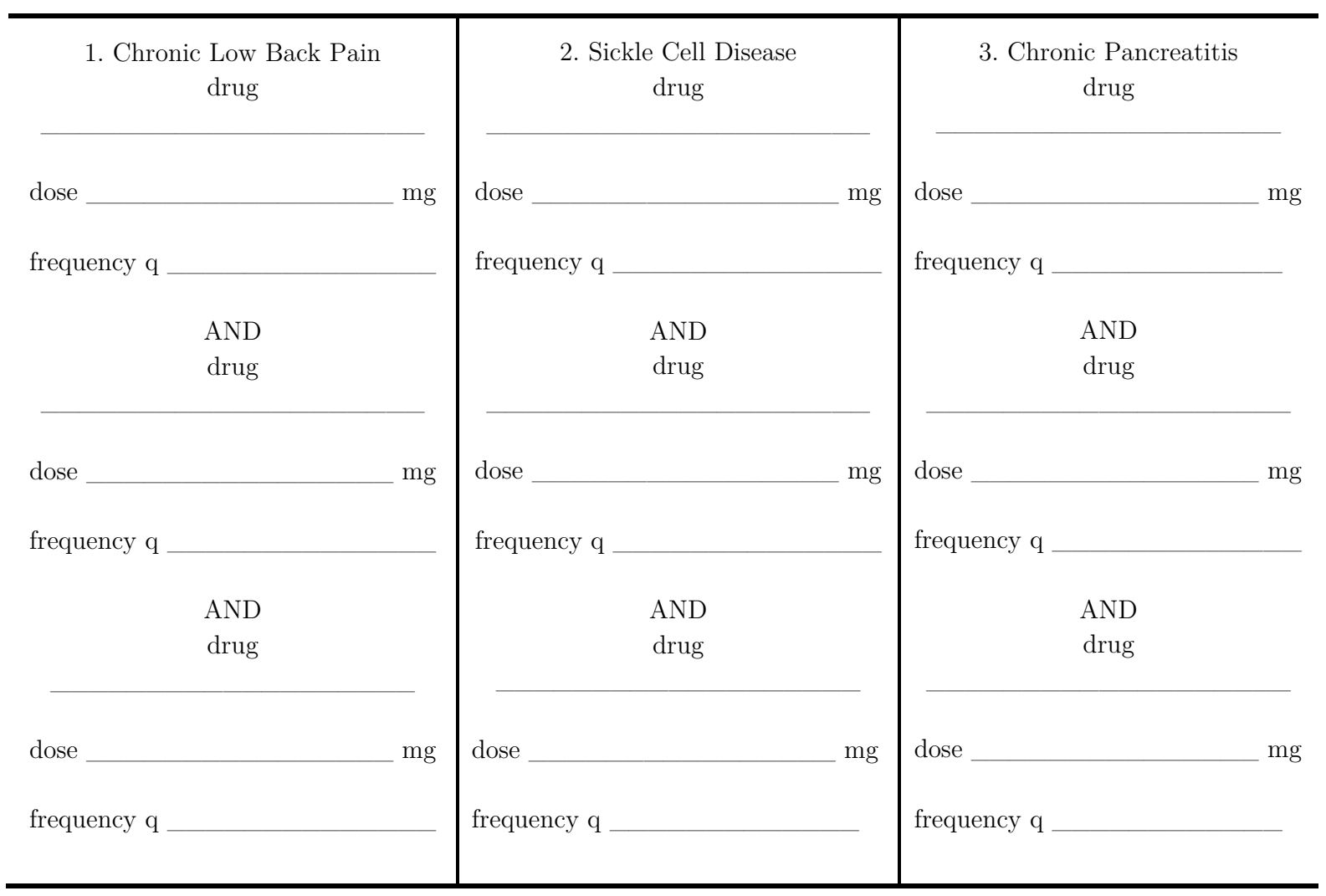

Now consider 100 patients similar to the case scenarios previously described. Estimate how many of these patients presenting to you for treatment of their pain would be addicted to opioids. (Addiction is defined as a behavioral pattern of compulsive drug use characterized by overwhelming involvement with the use of a drug, the securing of its supply, and a tendency to relapse after withdrawal).

\begin{tabular}{l|l|l}
\hline 4. Chronic Low Back Pain & 5. Sickle Cell Disease & 6. Chronic Pancreatitis \\
\hline
\end{tabular}




\begin{tabular}{l|l|l}
\hline$\overline{\text { (number between } 0 \text { and 100) }}$ & $-\overline{\text { (number between } 0 \text { and 100) }}$ & $\overline{\text { (number between 0 and 100) }}$ \\
\hline
\end{tabular}

Again, consider 100 similar patients. If these patients were to receive narcotics for ten days and then have them withdrawn, estimate how many would develop withdrawal symptoms like rhinorrhea and diarrhea.

\begin{tabular}{l|l|l}
\hline 7. Chronic Low Back Pain & 8. Sickle Cell Disease & 9. Chronic Pancreatitis \\
\hline$\overline{\text { (number between } 0 \text { and } 100)}$ & $-\frac{}{\text { (number between } 0 \text { and } 100)}$ & $\frac{\text { (number between } 0 \text { and } 100)}{}$ \\
\hline
\end{tabular}

Again, consider 100 similar patients. If these patients were to receive narcotics, estimate how many would develop severe complications.

\begin{tabular}{|c|c|c|}
\hline 10. Chronic Low Back Pain & 11. Sickle Cell Disease & 12. Chronic Pancreatitis \\
\hline (number between 0 and 100) & (number between 0 and 100) & (number between 0 and 100) \\
\hline
\end{tabular}

Using the scale below, please mark the extent to which you agree or disagree with the following statements with respect to each disease state listed (when indicated).

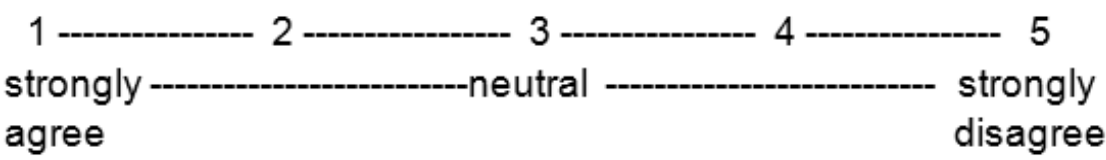

\begin{tabular}{|c|c|c|c|}
\hline & $\begin{array}{l}\text { Chronic Low } \\
\text { Back Pain }\end{array}$ & $\begin{array}{l}\text { Sickle Cell } \\
\text { Disease }\end{array}$ & Chronic Pancreatitis \\
\hline $\begin{array}{l}\text { I have had extensive experience treating patients with } \\
\text { problems like this. }\end{array}$ & 13 & 14 & 15 \\
\hline $\begin{array}{l}\text { Most of my experience with patients like these has } \\
\text { been in the emergency department. }\end{array}$ & 16 & 17 & 18 \\
\hline $\begin{array}{l}\text { I feel that I have had adequate training in the pain } \\
\text { management of these patients. }\end{array}$ & 19 & 20 & 21 \\
\hline $\begin{array}{l}\text { I am confident about my knowledge of narcotic } \\
\text { pharmacokinetics as it relates to this disease. }\end{array}$ & 22 & 23 & 24 \\
\hline $\begin{array}{l}\text { I worry about the possibility of addiction when } \\
\text { treating patients with this disease. }\end{array}$ & 25 & 26 & 27 \\
\hline $\begin{array}{l}\text { I feel that patients in this population are at a higher } \\
\text { risk of addiction than other pain patients. }\end{array}$ & 28 & 29 & 30 \\
\hline $\begin{array}{l}\text { These patients will sometimes lie about pain just to } \\
\text { get drugs. }\end{array}$ & 31 & 32 & 33 \\
\hline $\begin{array}{l}\text { When managing pain in this population, my goal is to } \\
\text { completely alleviate the patient's pain. }\end{array}$ & 34 & 35 & 36 \\
\hline
\end{tabular}




\begin{tabular}{|c|c|c|c|}
\hline $\begin{array}{l}\text { Patients in this population are adequately medicated } \\
\text { for their pain. }\end{array}$ & 37 & 38 & 39 \\
\hline $\begin{array}{l}\text { Patients in this population seeking treatment for pain } \\
\text { ask for too many drugs. }\end{array}$ & 40 & 41 & 42 \\
\hline $\begin{array}{l}\text { I sometimes doubt that these patients' pain episodes } \\
\text { are genuine. }\end{array}$ & 43 & 44 & 45 \\
\hline $\begin{array}{l}\text { I frequently monitor patients under my care to see if } \\
\text { they need anything for their pain. }\end{array}$ & 46 & 47 & 48 \\
\hline $\begin{array}{l}\text { Patients presenting in the emergency department are } \\
\text { well representative of the entire population. }\end{array}$ & 49 & 50 & 51 \\
\hline $\begin{array}{l}\text { The pain episodes of most patients within this } \\
\text { population are treated at home. }\end{array}$ & 52 & 53 & 54 \\
\hline $\begin{array}{l}\text { Different ethnic groups perceive pain differently. } \\
\text { (This question is NOT disease specific.) }\end{array}$ & & & 55 \\
\hline
\end{tabular}

56. Please rank the following sources of knowledge from which you may draw to manage pain in order of their importance, 1 as most important to 4 as least important.

( ) medical / nursing school

( ) reference materials

( ) your clinical experience

( ) other's clinical experience

57. What is your gender?

( ) male

( ) female

58. How old are you?

( ) years

59. What is your race?

( ) White (includes Arabian) - not Hispanic

( ) Black (includes Jamaican, Bahamanians and other Carribbeans) - not Hispanic

( ) Hispanic

( ) Asian and Asian American (includes Pakistanis, Indians and Pacific Islanders)

( ) American Indians (includes Alaskans)

60. What is your occupation?
( ) Attending physician
( ) Fellow - R4
Nurse
practitioner
( ) Fellow - R7
( ) Resident - R3
( ) Nurse
( ) Fellow - R6
( ) Resident - R2
) Other
Fellow - R5
( ) Resident - R1

61. In what year did you receive your most advanced medical degree (e.g., RN, LPN, MD)? 
( ) year

62. In what country was the medical or nursing school from which you graduated?

63. What is your current specialty within internal medicine?

$\begin{array}{lll}\text { ( ) Cardiology } & \text { ( ) Gastroenterology } & \text { ( ) Infectious disease } \\ \text { ( ) Clinical pharmacology } & \text { ( ) General medicine } & \text { ( ) Nephrology } \\ \text { ( ) Emergency medicine } & \text { ( ) Geriatrics } & \text { ( ) Pulmonary and } \\ \text { Critical care } & \\ \text { ( ) Endocrinology } & \text { ( ) Hematology/Oncology } & \text { ( ) Other }\end{array}$

